\title{
THE FOUNDING OF THE CONVENT OF THE CONGREGATION OF ST CATHERINE IN KRAKĖS IN THE 17TH CENTURY ${ }^{1}$
}

\author{
Vaida Kamuntavičiené \\ (Vytautas Magnus University)
}

\begin{abstract}
The Warmian (Ermland) Braniewo (Braunsberg) burgher Regina Protmann founded the community of St Catherine of Alexandria the Virgin Martyr in 1571, which the Holy See confirmed as a congregation in 1602. The congregation of sisters took an oath of poverty, chastity and obedience, agreeing to serve people, to care for those who were suffering, and to educate society. The ideas of the Sisters of St Catherine reached the Diocese of Samogitia in the 17th century. Its bishop, Jerzy Tyszkiewicz (Tiškevičius), founded the Krakès (Kroki) convent in 1645. Due to political, cultural and other circumstances, the transformation of this convent into a community of the Sisters of St Catherine took longer than expected, happening only in 1689 when the papal nuncio Giaccomo Cantelmi confirmed the community based on the rule of St Catherine. This article seeks to show the foundation process, revealing the differences between the Samogitian Sisters of St Catherine and those in the Warmian bishopric.
\end{abstract}

KEYWORDS: Congregation of the Sisters of St Catherine; Braniewo (Braunsberg); Samogitia, Krakès; Jerzy Tyszkiewicz; Kazimierz Pac.

\section{Introduction}

The Warmian bishopric (Ermland) was founded in 1243 in the Prussian lands that were conquered and settled by Germans in the 13th century. From 1466, this territory, known as Royal Prussia, belonged to the Kingdom of Poland, and in the First Partition of the Polish-Lithuanian Commonwealth it became part of Prussia. The German burgher Regina Protmann (1552-1613) ${ }^{2}$ from Braniewo (Braunsberg till 1645) in the Warmian bishopric, rejecting a wealthy

${ }^{1}$ This article was written with the support of the Research Council of Lithuania as part of project No S-MIP-17-30.

2 Pope John Paul II beatified her on 13 June 1999. 
secular life, established a community of devout virgins adjunct to the Church of St Catherine of Alexandria in 1571. The sisters took vows of poverty, chastity and obedience, and agreed to serve others, care for the sick and suffering, and educate society. The rules of the community of St Catherine of Alexandria, Virgin and Martyr, were written in 1583 , reformed in 1602, and confirmed by the papal nuncio Claudio Rangoni in Vilnius.

The Braniewo Sisters of St Catherine were born out of the implementation of resolutions reached at the Council of Trent (1545-1563), in an era of reform of the Catholic Church. It was at this time that monastic life underwent a revival, with new monasteries being established. It is believed that Protmann's decision was influenced by the Braniewo Jesuits. Even though the Council of Trent had foreseen the strict confinement of women in convents, in practice, the resolutions of the Council were in some cases interpreted quite liberally. ${ }^{3}$ The Sisters of St Catherine were confirmed as an apostolic institution, whose members were only allowed to take simple vows and did not have to adhere to strict religious enclosure. They could leave the cloister for the purposes of nursing the sick and providing education. The Sisters of St Catherine rejected choirs made up solely of nuns (there were usually two types of choir in convents: choralists, whose main role was to sing the Liturgy of the Hours, and the lay sisters, or soeurs converses, who carried out routine everyday tasks in the convent); instead, all the sisters spent an equal amount of time in prayer and at work, combining contemplation with serving the community.

Protmann's ideas were highly successful: soon, congregations of the Sisters of St Catherine were established in other cities in the Warmian bishopric, in Orneta (Wormditt) in 1586, in Lidzbark Warmiński (Heilsberg) in 1587, and in Reszel (Rößel) in 1593. ${ }^{4}$ These were German convents, with the sisters mostly being burghers of German origin. ${ }^{5}$ By the 17 th century, the ideas of the Sisters of St Catherine had reached the Grand Duchy of Lithuania. A convent for these sisters was created in Krakès (Kroki) about 360 kilometres from Braniewo, until the end of the 19th century the only one outside the Warmian bishopric.

${ }^{3}$ M. Borkowska, Zakony żeńskie w Polsce w epoce nowożytnej (Lublin, 2010), p. 216.

${ }^{4}$ J. Vaišnora, 'Kotrynietès', in: Lietuviu enciklopedija, Vol. 12 (Boston, 1957), p. 498.

${ }^{5}$ M. Borkowska, Panny siostry w świecie sarmackim (Warszawa, 2002), pp. 87-88. 
In 1993, the Polish historian Grzegorz Błaszczyk claimed that there was practically no information about the Sisters of St Catherine of Krakès, except for the information given in the historical work Žemaičiu vyskupystè (The Diocese of Samogitia) by Motiejus Valančius, the Bishop of Samogitia, in 1848, and certain data in encyclopedias, such as the information presented by Jan Marek Giżycki in the encyclopedia Podręczna Encyklopedia Katolicka in $1910 .{ }^{6} \mathrm{He}$ did not mention that the Lithuanian émigré historians Juozas Vaišnora and Bronius Kviklys had also written encyclopedic entries about the Sisters of St Catherine. ${ }^{7}$ The first broader history of the Lithuanian Sisters of St Catherine was written in German in 1940 by Fr Paul Bludau, a priest originally from the Klaipeda district (Memelland). ${ }^{8}$ This typewritten 16-page-long text was never printed. Based on information from Valančius and material gathered during visitations, it mentioned important moments in the lives of Lithuania's Sisters of St Catherine. At present, this work has little research value, but it might prove to be important for revealing a specific historiographical position.

After the publication of Błaszczyk's article, the historians Kazys Misius and Romualdas Šinkūnas, and the art researcher Rūta Janoniene, wrote about the Krakès convent, albeit rather dryly. ${ }^{9}$ A breakthrough in research into the congregation of the Sisters of St Catherine came about with the works of the Polish historian and sister in the congregation Barbara Marija Gerarda Sliwińska, ${ }^{10}$

${ }^{6}$ G. Błaszczyk, 'Stan badań nad klasztorami diecezji żmudzkiej', in: Zakony $i$ klasztory w Europie Środkowo - Wschodniej. X-XX wiek. Materiaty międzynarodowego seminarium pod tytułem 'Atlas ruchu zakonnego w Europie Środkowo - Wschodniej. X-XX wiek’, Lublin, 25-27 listopada 1993, eds. H. Gapski, J. Kłoczowski (Lublin, 1999), p. 268.

${ }^{7}$ J. Vaišnora, 'Kotrynietès', pp. 498-500; B. Kviklys, Mūsu Lietuva, t. 2 (Boston, 1965), pp. 417-422; idem., Lietuvos bažnyčios, t. 3 (Chicago, 1983), pp. 250-253.

8 P. Bludau, 'Die Geschichte der Katharinerinnen der Provinz Litauen', Braunsberg, 1940 (typewritten), Archiwum Prowincjonalne sióstr Katarzynek $w$ Braniewie (APSK), ZG-G-a-1.

9 K. Misius, R. Šinkūnas, Lietuvos kataliku bažnyčios (žinynas) (Vilnius, 1993), pp. 160-161; R. Janonienè, 'Krakių kotryniečių vienuolynas', in: Lietuvos vienuolynai. Vadovas (Vilnius, 1998), pp. 126-127.

${ }^{10}$ B. Śliwińska, 'Zgromadzienie sióstr świętej Katarzyny Dziewicy Męczennicy na Litwie (1645-1995)', in: Studia Warmińskie, nr. XXXIII (1996), pp. 273-293; eadem., Dzieje zgromadzienia sióstr Świętej Katarzyny Dziewicy i Męczennicy 1571-1772 (Olsztyn, 1996; second edition 1998). For this paper, I used the second, newer edition, also, the translation into German found in: eadem., Geschichte der Kongregation der Schwester der heiligen Jungfrau un Martyrin Katharina 1571-1772 (Münster, 1999). 
and the German historian Relinde Meiwes, ${ }^{11}$ which were initiated by the sisters themselves, and had the intention of presenting the congregation's history from its founding until the Second Vatican Council. Śliwińska's task was to write a history of the congregation from its founding until 1772. The book reveals comprehensively the history of convents in the Warmian bishopric, their legal status, spirituality, and charitable and educational activities. However, more attention could have been paid to the Sisters of St Catherine in Krakès, and certain conclusions she reached could still be disputed. Meanwhile, Meiwes, who studied the congregation's history after 1772 , laconically repeated the ideas of earlier historians about the founding of the Krakès convent, which fell outside the chronological boundaries of her research. But Meiwes was the first to notice the more significant differences between the sisters in Warmia and in Samogitia. The Vytautas Magnus University student Roberta Grigaliūnaite focused on the structure of the Krakès convent of the Sisters of St Catherine in the 17th and 18th centuries, ${ }^{12}$ although she did not give a more thorough analysis of the course of the convent's foundation itself. The article by Liudas Jovaiša, in which he discusses the phenomenon of devout women in Samogitia in the 17th and 18th centuries, helps us better understand the circumstances behind the convent's establishment. ${ }^{13}$

The Lithuanian Sisters of St Catherine themselves were interested in the history of their convent. The Lithuanian-language teacher $\mathrm{Sr}$ Teofile Marija Benjamina Šopyte wrote a manuscript history of the congregation's sisters in Lithuania in the 1980s, which was translated into Polish and German, and also helped Śliwińska and Meiwes write the parts of their books relating to the Sisters of St Catherine in Lithuania. ${ }^{14}$ Šopyte's work allows us to understand the attitude of Lithuania's 20th-century sisters to their own history.

${ }^{11}$ R. Meiwes, Von Ostpreußen in die Welt. Die Geschichte der ermländischen Katharinenschwestern (1772-1914) (Paderborn, 2011); eadem., Klosterleben in bewegten Zeiten. Die Geschichte der ermländischen Katharinenschwestern (1914-1962) (Paderborn, 2016).

12 R. Grigaliūnaite, 'Krakių kotryniečių vienuolijos sudètis XVII-XVIII a.', in: Lietuvos Didžiosios Kunigaikštystès moteru vienuolijos: istorija ir paveldas, ed. A. Vasiliauskienė (Kaunas, 2014), pp. 141-154.

${ }^{13}$ L. Jovaiša, 'Neinstitucinė moterų vienuolystė? Davatkos Žemaitijoje XVIIXVIII a.', in: Lietuvos Didžiosios Kunigaikštystès moteru vienuolijos, pp. 47-68.

${ }^{14}$ B. Šopyte, 'Kaip Dievas nori', 1989 (typewritten), Krakiu kotryniečiu archyvas (Archive of the Sisters of St Catherine in Krakès, KKA); eadem., 'Wie Gott will. Katharinenschwestern in Litauen', 1989 (translation, typewritten), KKA. The Polish 
Research into the Krakès convent of the Sisters of St Catherine is complicated by a fire that broke out there in 1863, during which all the archival documents that had been amassed over the ages were destroyed. Today, the main research sources for the first decades of the convent's existence could be documents kept in other archives, primarily the curias of the Krakès parish and the Diocese of Samogitia, and the papal curia in Rome. A number have been published: the visitations of the Diocese of Samogitia in the 17th century, the Bishop of Samogitia's relationals (letters) to Rome, etc. ${ }^{15}$ The remains of the old archive of the convent of the Sisters of St Catherine are kept at the congregation's convent in Kaunas. One of the oldest documents is a book about the Krakès nuns which their chaplain Kazimierz Józef Pikturna started to write in $1788,{ }^{16}$ in which he presented a brief history of the convent, copies of the more important documents, a register of the Sisters of St Catherine he was aware of, indicating (if known) the dates of birth, vows and death, and origins. The next important sources are the rules of the Krakès Sisters of St Catherine confirmed in 1673 by Kazimierz Pac, the Bishop of Samogitia, and the accompanying documents that survived in duplicates made in the 18th and 19th centuries. One of them is the book by Pikturna, the other being written up in a separate book together with amendments made to the rules in the 19th century. ${ }^{17}$ Copies of 17 th-century documents (or information

translation is mentioned in Śliwińska's book: B. Śliwińska, Dzieje Zgromadzienia, t. 1, p. 116. The German translation is kept in the German archive of the Sisters of St Catherine in Münster (Archiv der Provinz der Katharinenschwestern in Münster), while the Polish translation is kept at the Archive of the Sisters of St Catherine in Braniewo (Archiwum Prowincjonalne Sióstr Katarzynek w Braniewie).

${ }^{15}$ Relationes status dioecesium in Magno Ducatu Lithuaniae, vol. 1: Dioeceses Vilnensis et Samogitiae, ed. P. Rabikauskas (Roma, 1971); Codex Mednicensis seu Samogitiae dioecesis, Vol. 2, ed. P. Jatulis (Roma, 1989); Žemaičiu vyskupijos vizitacijų aktai (1611-1651 m.), ed. L. Jovaiša (Vilnius, 2011); Žemaičiu vyskupo Kazimiero Paco 1675-1677 m. sudaryti vizitaciju aktai, ed. M. Paknys (Vilnius, 2011).

16 Documents relating to the convent's history during the period 1919-1948, KKA, b. 4, 1. 48. The book probably survived the fire of 1863 because it was kept by the chaplains who continued to register Sisters of St Catherine in the 19th century. At present, it is kept in the Krakess Archive of the Sisters of St Catherine in Kaunas: 'Księga osob szlachetnie urodzonych w konwencie wielebnych Panień krokowskich', KKA, b. 1. (here and elsewhere in the article, the language in manuscript sources has not been corrected).

17 'Reguła Panien zakonnych S. Katarzyny Męczenniczki w dyecezyi Zmudzkiey w m. Krokach', KKA, 1. 2-11v; 'Księga osob szlachetnie urodzonych w konwencie wielebnych Panień krokowskich', KKA, b. 1, 1. 61v-65. 
about the situation in the 17th century) have survived in material from visitations made to the convent in later years, and in inventories kept in the Lithuanian State History Archives, the Kaunas Archdiocese curia archives, and other archives. Some of the more important 17th-century documents from the Kaunas Archdiocese curia archives and the archive of the congregation's convent in Krakès, currently kept in Kaunas and in the homes of some of the sisters, were collected and published by Śliwińska. ${ }^{18}$

The most important aim of this article is to reveal the circumstances behind the foundation of the Krakès convent of the Sisters of St Catherine, and the course of this process, and also, to show any links between Krakès and Braniewo, to show features of the adaptation of the congregation's rule in Krakès, and to identify the unique characteristics of the sisters of the congregation in the Grand Duchy of Lithuania (GDL).

\section{The founding of the Krakès convent in $\mathbf{1 6 4 5}$}

Krakès was a domain that belonged to the Bishop of Samogitia, ${ }^{19}$ where the Catholic Church supported the Bishop of Samogitia's donation in the second half of the 15th century. ${ }^{20}$ The parish priest at Krakès was the famous Samogitian canon Mikalojus Daukša, the author of the first Lithuanian religious books. ${ }^{21}$ The parish had an

18 Note by J. Tyszkiewicz, Alsèdžiai, 23 February 1645 (the Polish publication indicates the wrong date [3 February 1646], which has been corrected in the German translation) (No 33); from the Warmian bishop J.S. Wydżga to the superior M.S. Siemaszkówna, Heilsberg, 9 July 1668 (No 36); the note by P. Parczewski, which confirmed the rule of 1602 translated into Polish, Alsèdžiai, 21 February 1673 (No 37); the note by G. Cantelmi, which confirmed the rule of the Krakès Sisters of St Catherine, Warsaw, 28 March 1689 (No 38). Published in: B. Śliwińska, Dzieje Zgromadzienia, t. 1, pp. 170-173. Translation of the documents into German: B. Śliwińska, Geschichte der Kongregation, pp. 184, 186-188. The first document is kept in the Kaunas Archdiocese Curia Archives (a repeated publication was in: Žemaičiu vyskupijos vizitaciju aktai (1611-1651 m.), pp. 321-322), while the other three documents are kept in the KKA files: 'Księga osob szlachetnie urodzonych w konwencie wielebnych Panień krokowskich', KKA, b. 1, 1. 61, 65; 'Reguła Panien zakonnych S. Katarzyny Męczenniczki w dyecezyi Zmudzkiey w m. Krokach', KKA, 1. 11-13.

${ }^{19}$ R. Meiwes, Von Ostpreußen in die Welt, p. 61.

${ }^{20}$ G. Błaszczyk, Diecezja żmudzka od XV wieku do początku XVII wieku. Ustrój (Poznań, 1993), p. 161.

21 J. Lebedys, Mikalojus Daukša (Vilnius, 1963). 
altaria for priests no longer conducting services, ${ }^{22}$ and a congregation of Christian Doctrine Fathers was established in $1644 .{ }^{23}$ Around the middle of the 17th century, the new wooden Church of the Resurrection, the Visitation of the Virgin Mary and St Matthew the Apostle, was built in Krakès, which was consecrated by the Bishop of Samogitia, Jerzy Tyszkiewicz (bishop from 1633 to 1649), on 19 September 1649. In 1651, the ruler John Casimir Vasa founded an almshouse, which was allocated the village of Pipliai and 18 voloks of land, to feed 12 paupers. ${ }^{24}$ Krakès became the centre of the newly formed Krakès deanery. It was under these conditions that devout young women from noble families arrived in Krakès to dedicate their lives to the glorification of the Lord.

According to data from Jovaiša's research, devout (from the Latin devoto, meaning pious) women, from a specific social group, would congregate around parish churches in the 17th and 18th centuries in Samogitia, affording them a special status within the Church structure. $^{25}$ We can distinguish two main forms of servitude to the Lord among these devout women: the production and maintenance (cleaning and mending) of liturgical vestments, and prayer (saying the Rosary and singing hymns). Sometimes devout women would live together, creating 'a more integrated community', which Jovaiša calls a 'little convent'. The characteristics of this kind of little convent can be noticed in Krakès in the mid-17th century. ${ }^{26}$

The history of the Krakès convent that was written at the end of the 18th century by the chaplain Pikturna states that the establishment of the Sisters of St Catherine in Krakès could be associated with a community of noble women that had settled in Krakès before 1640, occupying a house under the care of the parish priest. This community had a superior, they took vows of poverty, chastity and obedience to the priest, and promised to pray to God

${ }^{22}$ Krakès parish visitation, 2 January 1721, Lietuvos valstybès istorijos archyvas (Lithuanian State Historical Archives, LVIA), f. 669, ap. 2, b. 260, 1. 136.

${ }^{23}$ Note by J. Tyszkiewicz, 2 June 1644, ibid., f. 1671, ap. 4, b. 369, 1. 241; Žemaičiu vyskupo Kazimiero Paco 1675-1677 m. sudaryti vizitaciju aktai, p. 703.

${ }^{24}$ M. Jučas, Lietuvos parapijos XV-XVIII a. (Vilnius, 2007), p. 133.

${ }^{25}$ L. Jovaiša, 'Neinstitucinè moterų vienuolystè', pp. 47-51. Jovaiša notes that devout virgins were a phenomenon peculiar to Samogitia, and not so common in the Diocese of Vilnius.

${ }^{26}$ Ibid., pp. 56-59, 52. 
and St Mary. ${ }^{27}$ As the date 'before 1640' is rather vague, historians have tried to find out when the Sisters of St Catherine could have started their activities in Krakès, and have come up with various dates for the convent's beginning. Roberta Grigaliūnaite demonstrates this problem in her article about the Sisters of St Catherine. ${ }^{28}$ Sometimes it is said that the sisters became established in Krakès in 1615, during the times of Bishop Mikołaj Pac of Samogitia. The Jesuits were becoming established in Kražiai at this time, so it could be that they encouraged the Sisters of St Catherine to settle in the Diocese of Samogitia. Another date, 1631-1633, is related to Bishop Melchior Eliaszewicz-Gejsz (d. 1633) of Samogitia. He visited the congregation in Braniewo in 1631, becoming acquainted with their way of life, and might have wanted to establish a similar convent in his diocese. ${ }^{29}$ However, these are only presumptions; we have no sources to confirm this information. These facts show that the processes that took place in the Warmian bishopric were known about in Samogitia, and that clergy from both dioceses cooperated rather closely.

During the visitation to the Krakès parish on 10 November 1648, it was noted that Bishop Jerzy Tyszkiewicz of Samogitia allowed the noblewoman Barbara Zapolska (Zapolskaite) to have a house built and to live there, where other virgins could also come and live with her. The visitation documents include a copy of a note written in Alsèdžiai on 23 February 1645 by Bishop Jerzy Tyszkiewicz which mentions that the noblewomen Srs Barbara and Anna Zapolska, from the Krakès parish, had lived a life of chastity for a long time, and asked to be more closely bound to the parish church. As a result, they were allocated a place to live on the edge of the city near the river Smilga, on the priest's land, which was unused at the time. They were given permission to build a house for themselves and their successors, and in return, they were under an obligation to serve the church and take care of the laundry. The priest was to provide them with soap, starch and firewood. These young women had to respect the bishop's rules and his authority, remain outside the jurisdiction of secular

27 'Księga osob szlachetnie urodzonych w konwencie wielebnych Panień krokowskich', KKA, b. 1, 1. 16.

${ }^{28}$ R. Grigaliūnaitè, 'Krakių kotryniečių vienuolijos sudètis XVII-XVIII a.', pp. 141-143.

${ }^{29}$ R. Janonienè, 'Krakių kotryniečių vienuolynas', p. 126. 
laws, and obey the bishop and his appointed visitors. The priest, his successors and other men were forbidden to go there. ${ }^{30}$ The vow of chastity, stability and obedience were important indicators of a monastic life.

Material from a visitation to the Krakès convent of the Sisters of St Catherine in 1805 contains another copy of a notice from Bishop Jerzy Tyszkiewicz of Samogitia, dated 5 July 1645, in which the bishop states that there were noblewomen in the diocese who had willingly taken vows of chastity, who were living near various churches and in houses under no strict rules or orders. The bishop gave them permission to live together in Krakès, and to have a 'mother superior' whom they had to listen to, while the superior had to comply with the bishop's orders. This community was allowed to build a chapel, and also to care for the old and infirm. They were given 13 morgens of arable land. ${ }^{31}$ Bludau and Jovaiša claim that it was specifically this founding notice issued by Tyszkiewicz that marked the official establishment of the community in Krakess. ${ }^{32}$ Indeed, having a mother superior and founding their own chapel was firmer evidence of the existence of a monastic community. The initial endowment was increased with Bishop Tyszkiewicz' note of 10 September 1647, whereby he allocated a garden to the devout virgins of Krakes. ${ }^{33}$

These actions were summarised in Pikturna's history of the convent in the late 18th century. He writes that on 23 February 1645, Bishop Jerzy Tyzkiewicz of Samogitia granted the noblewomen lands, ensuring them better living conditions and stability. On 5 July 1645, he issued them with a privilege permitting the construction of a convent and granting them 13 morgens of land. On 10 September 1647, he granted a third privilege, allocating them a garden. ${ }^{34}$

30 Žemaičiu vyskupijos vizitacijų aktai (1611-1651 m.), pp. 321-322.

${ }^{31}$ Note by J. Tyszkiewicz, 5 July 1645, in: Visitation of the Krakes convent of the Sisters of St Catherine, 16 February 1805, LVIA, f. 1671, ap. 4, b. 369, 1. $10-10 \mathrm{v}$.

32 P. Bludau, 'Die Geschichte der Katharinerinnen', APSK, ZG-G-a-1, 1. 2; L. Jovaiša, 'Neinstitucinè moterų vienuolystè', p. 56.

33 Žemaičiu vyskupijos vizitacijų aktai (1611-1651 m.), p. 322.

34 'Księga osob szlachetnie urodzonych w konwencie wielebnych Panień krokowskich', KKA, b. 1, 1. 16. 
Even though the foundations were laid for a convent in Krakès in 1645 , in a relational to Rome written in Alsèdžiai on 15 August 1646, Bishop Jerzy Tyszkiewicz of Samogitia made no mention of the Krakès convent, stating that there was only one convent in his diocese, that of the Benedictine nuns in Kražiai, the foundation being made possible by Chryzostom Wolodkiewicz (Valadkevičius) on 12 October 1639, and becoming operational around $1643 .{ }^{35} \mathrm{He}$ also mentioned the devout women living by churches, providing more data about devotees at the bishop's cathedral in Varniai. ${ }^{36}$ Thus, the inhabitants of the Krakès convent were merely devout women, in his view, to whom he granted a particular organised form of being.

Material from the 1648 visitation to the Krakes parish provides us with more thorough data on how the Krakès community lived at this time. As the purpose of a visitation is to monitor whether the requirements of the Church are being duly followed, and to take note of any failings, the visitor cannot let any shortcomings in religious or material life go unnoticed. In this document, it was written that Barbara Zapolska 'wasted others' money, appropriated votive offerings donated to the Church, misused alcohol, gallivanted around with men, and would visit a witch living in a nearby village'. ${ }^{37}$ Marta Marcinowiczówna (Marcinavičiūtè), who lived with Barbara, claimed that this behaviour had gone on for two years. Another virgin, Elisabetha Mackiewiczówna (Mackevičiūtè), who also lived with Barbara, confirmed the claims about her inappropriate behaviour. ${ }^{38}$ Understandably, Barbara was dismissed from the Krakès community for leading such a scandalous life. Barbara's sister Anna Zapolska, on the other hand, behaved in a proper manner, and continued to live in the parish. It appears that Anna suffered

35 V. Kamuntavičienè, Kauno benediktiniu vienuolyno tyrimai, t. 1: Kauno benediktiniu vienuolyno istorija (Kaunas, 2016), pp. 33-36.

${ }^{36}$ Relationes status dioecesium in Magno Ducatu Lithuaniae, vol. 1, pp. 281, 285. 'Monialium conventus in mea dioecesi non nisi unicus, loci Crosensis Ordinis S. Benedicti, noviter a quodam nobili milite erectus et suis proventibus dotatus...'; 'Omnium monasteriorum regularium in dioecesi mea costitunt personae exceduntque numerum centum decem, praeter religiosas moniales Ordinis $S$. Benedicti et alias devotas virgines ad ecclesias manentes.'

${ }^{37}$ L. Jovaiša, 'Neinstitucinè moterų vienuolystė', p. 53.

38 Žemaičiu vyskupijos vizitacijų aktai (1611-1651 m.), pp. 322-324. Śliwińska claims that Marcinowiczówna was named Marta, or at least that is how the unclear source inscription 'Nartowna' has been deciphered. See: B. Śliwińska, Dzieje Zgromadzienia, t. 1, p. 117. 
for her sister's transgressions, as the apostolic visitor claimed that they had nothing in common other than being from the same family. It is likely that, following this occurence, there was much stricter selection of candidates to the Krakès community, as in later years there is no further mention of young women displaying such inappropriate behaviour.

These facts show that the devout women of Krakès were quite important in the parish, controlling certain financial resources and Church objects. The women also had a privileged place for prayer in the church, a special enclosed pew with grates and curtains. But during the visitation of 1648 , this situation was deemed unacceptable and had to be changed. The priest was banned from publicly accepting the devout women's vows, so similar to those taken by nuns. Taking vows in public was reserved for the bishop, and could only be done with his approval. The visitor also demanded that the closed prayer space for devout women in the Krakès church be dismantled, the grates and curtains removed, and that it be moved closer to the choir and reserved for dignitaries. The devout women were ordered to kneel in an ordinary pew or on the floor. ${ }^{39}$

\section{A community of devout women, or Sisters of St Catherine?}

The apostolic visitor to the Krakès parish in 1648 did not identify the Krakès devout women as Sisters of St Catherine. In order to become a convent of this congregation, they had to establish ties with Braniewo, accept the rule of the Congregation of St Catherine and abide by it at their convent, taking vows in accordance with the rule. Convents of the Congregation of St Catherine that were established in other locations in the Warmian bishopric, at Orneta, Lidzbark Warmiński and Reszel, received visits from several sisters from Braniewo, who would teach the local young women the way of life of the sisterhood. Having carried out their mission, the sisters from Braniewo would return to their convent after a year or so. This was the usual way in which new convents of the Congregation of St Catherine were established. We may ask, when and how was this done in Krakès?

Valančius wrote that in 1645, Bishop Jerzy Tyszkiewicz of Samogitia became acquainted with a nun from the Congregation of St Catherine

${ }^{39}$ L. Jovaiša, 'Neinstitucinė moterų vienuolyste’', pp. 52, 54. 
in Torun (he spent three months there, from the end of August until the end of November 1645, participating in a Catholic and Protestant congress which he oversaw), and invited her to Krakes, whereupon a wooden church and convent were built. ${ }^{40}$ Śliwińska claims it is unlikely that Tyszkiewicz could have met one of the sisters of the congregation in Torun, as it did not have a convent in the city, and the Sisters of St Catherine never travelled far from their towns, trying not to go beyond its boundaries at all. Even though Śliwińska doubted that Tyszkiewicz met a Sister of St Catherine in Torun, she tends to agree with Valančius' idea that the sisters at some point had made it to Krakès. Śliwińska states that Tyszkiewicz could have become familiar with the activities of the Sisters of St Catherine indirectly, as they were well known in Warmia. ${ }^{41}$ Other authors agree. Šopyte writes that a sister of the congregation had arrived from Warmia and settled in Krakès, whereupon community life according to the rule of the Congregation of St Catherine commenced. ${ }^{42}$ Borkowska states that in 1646 the bishop invited a sister from Warmia to see to the proper formation of the young women. ${ }^{43}$ The problem is that, apart from Valančius (who might have based his account on sources we are unaware of today or have not survived, which is why it cannot be checked), there are no sources that could testify to the visit of a Warmian Sister of St Catherine to Krakès in 1645. Valančius does mention the arrival of one sister of the congregation; however, according to the rule, that would have been quite impossible, as the sisters could only leave the convent in pairs.

The Krakès chaplain Pikturna wrote in the book about the Krakès convent in 1788 how Barbara and Anna Zapolska had been mentioned in the note by Bishop Jerzy Tyszkiewicz on 13 September

${ }^{40}$ M. Valančius, 'Žemaičių vyskupystè', Raštai, t. 2 (Vilnius, 1972), p. 323. 'Metuose 1645 Jurgis Tiškevyčia, vyskupas, dèl stigavonès su netikèliais nuvažiavęs i miesta Torune, gavo pažintis su viena šv. Kotrynos zokaninke, katrai ir isakè, kad $i$ Žemaičius atvyktu. Ta ịkandin Tiškevyčios atvažiavo $i$ Varnius, o vyskupas, išdirbęs Krakèse medžio bažnyčia su klioštorium, anai atidavè' (In the year 1645, Jerzy Tyszkiewicz, the Bishop, on the grounds of battling non-believers, travelled to the city of Torun, and met one of the sisters of St Catherine, to whom he ordered to go to Samogitia. She followed Tyszkiewicz to Varniai, and the bishop, who had built a wooden church and cloister in Krakès, gave it to her).

${ }^{41}$ B. Śliwińska, Dzieje Zgromadzienia, t. 1, pp. 114-115.

42 B. Šopyte, 'Kaip Dievas nori', p. 83.

${ }^{43}$ M. Borkowska, Zakony żeńskie w Polsce w epoce nowożytnej, p. 341. 
1646, in which he allowed them to live as noblewomen beside the parish church; but it is not known whether they had a profession, or when they died. ${ }^{44}$ In her interpretation of this note, Šopyte claims that it was actually on 13 September 1646 that they took their solemn vows. Based on Šopyte, Śliwińska continues to develop the erroneous idea that Barbara and Anna must have already passed their year-long novitiate, as set out in the rules, while their formation would have unquestionably been overseen by Sisters of St Catherine from Warmia. ${ }^{45}$

In her attempts to find Warmian sisters of the Congregation of St Catherine in Krakès, Śliwińska believes that the nuns Marta Marcinowiczówna and Elisabetha Mackiewiczówna, who were mentioned in the visitation of 1648, could have been Sisters of St Catherine from Warmia. She tries to calculate when they could have arrived, stating that it was probably after the visit of Bishop Tyszkiewicz to Torun, and no earlier than November $1645 .{ }^{46}$ These sisters are not mentioned in any other surviving sources. Śliwińska believes that they could have returned to Warmia, ${ }^{47}$ although there are no documents to suggest their being in Warmia either. Nor are these two nuns on the list of sisters at Krakès compiled by Pikturna in 1788. ${ }^{48}$ Note, however, that this list was not complete, being written over a century after the events.

The fact that these two sisters had arrived from Warmia is questionable. It is strange that the apostolic visitor of 1648 made no mention of them. Even more strange is that a sister arriving from Warmia whose main aim would have been to teach the devout women in Krakess to live according to the rule of the Congregation of St Catherine could not have noticed Barbara's inappropriate

44 'Księga osob szlachetnie urodzonych w konwencie wielebnych Panień krokowskich', KKA, b. 1, 1. 17v. E.g., an entry about Barbara: '1646 września 13, WJPanna Barbara Zapolska, o ktorey wzmianka JWJ Xiędza Jerzego Tyszkiewicza Biskupa Żmoydzkiego pod ta data pozwalający list mieszkania przy kosciele parafialnym, jako szlachetnie urodzoney, czyni. Która niewiadomo czy czyniła jaka professyję czyli nie, y ktorego roku umarla'. A similar entry was made about Anna Zapolska. In fact, no entry made by Tyszkiewicz from that day is known to have survived.

${ }^{45}$ B. Šopyte, 'Kaip Dievas nori', p. 83; B. Śliwińska, Dzieje Zgromadzienia, t. 1, p. 116.

46 Ibid., p. 275.

47 Ibid., p. 117.

48 'Księga osob szlachetnie urodzonych w konwencie wielebnych Panień krokowskich', KKA, b. 1. 
behaviour for two years, and not informed the Church superiors or tried to discipline Barbara herself. The surviving lists of Warmian Sisters of St Catherine show that the surnames of the Warmians were mostly Germanic. Slavic surnames were very rare, so it is unlikely that two Polish-speaking nuns could have arrived at this time, who would then have been sent to Krakès. Even several dozen years later, finding a Polish-speaking Sister of St Catherine in Warmia was problematic. In addition, the arrivals would have brought with them a rather strict set of rules, which would have been recorded in documents, regardless of the sparseness of these kinds of sources today. Also, the visitation of 1648 would have referred to the establishment as being a convent of the Sisters of St Catherine, and not simply a community of devout virgins.

Śliwińska claims that the visit of the Warmian sisters in Krakès is confirmed in the surviving visitation acts of the Krakes convent and the bishop's grants to the convent. ${ }^{49}$ However, in actual fact, no surviving documents today mention any visit of a sister of the Congregation of St Catherine from Warmia to Krakès in the period 1645 to 1648 . Historians are left with the choice of whether or not to believe Valančius. In my opinion, the information Valančius had about the visit of the Warmian sisters to the Krakès convent at the time of its establishment is inaccurate, and cannot be confirmed in other sources.

Soon after the visitation of 1648 , new members joined the Krakès community. Barbara's behaviour did not break up the fragile young convent. Perhaps it even had the opposite effect: the visitor's attention and corrected indiscretions strengthened the community.

Jovaiša found an entry in the book of the Bishop of Samogitia's circulars stating that on 21 September 1649, on the Feast of St Matthew, in the presence of Bishop Tyszkiewicz and with the participation of the parish priest Albertus (Wojciech) Witkiewicz (Vitkevičius), and other honoured guests, during Mass, the noblewomen Anna Nargełówna (Nargèlaitè), Anna Marcinówna (Martynaitė) and Regina Grymżanka (Grimžaitè) 'publicly took vows of chastity and accepted the veil; the bishop blessed their rings and crowns, ordering them to live for all their years by the Krakès Church. ${ }^{50}$

49 B. Śliwińska, Dzieje Zgromadzienia, t. 1, p. 115.

${ }^{50}$ L. Jovaiša, 'Neinstitucinè moterų vienuolystè', p. 52. Thanks to L. Jovaiša for pointing out these documents: entry in the Book of the Bishop of Samogitia's Circulars (Liber processuum dispositiones pastorales episcoporum Samogitiae), LVIA, 
This is the earliest-known mention in sources of the Krakès sisters taking vows. I would say that, until then, the devout women of Krakès would take their simple vows in the presence of the priest only. Once this was banned after the visitation of 1648, from 1649 vows were accepted by the Bishop of Samogitia Jerzy Tyszkiewicz. But it is not mentioned that these vows were taken in accordance with the rule of the Congregation of St Catherine.

In the list of sisters compiled by Pikturna in 1788 , it was written that these three sisters, along with a fourth, Barbara Narbutówna Narbutaite), were mentioned on a list for the sale of the house belonging to the Krakès parish priest, Wojciech Witkiewicz, on 22 September 1649. However, on the previous page in this same book, it is written that the Krakès sisters had bought with their own money a plot of land with buildings from the Krakès parish priest Witkiewicz on 21 September 1649, and that this transaction had been authorised on 25 February 1650, with the permission of the Samogitian capitula, by Jerzy Tyszkiewicz, who was then Bishop of Vilnius, and confirmed on 14 January 1651 by the new Bishop of Samogitia Piotr Parczewski (Parčevskis, bishop from 1649 to 1659$).{ }^{51}$ Thus, the transaction of the sale of the house had been signed on the same or the following day that the three sisters mentioned took their vows. Religious vows went hand-in-hand with material obligations.

Three nuns were listed separately in the visitation of 1820 , A. Zapolska, R. Grymżanka and B. Narbutówna, and were identified as having contributed to the establishment of the convent, investing their own money in the creation of the convent's material base. ${ }^{52}$ In time, it was specifically these three sisters who were credited with enhancing the convent in a material sense. In general, it could be said that it was not just the Bishop of Samogitia but also the Sisters of St Catherine who made material contributions to the convent.

f. 669 , ap. 3, b. 4464, 1. 105; note by J. Tyszkiewicz, Krakès, 24 September 1649, Book of the Bishop of Samogitia's Circulars, ibid., 1. 108-109.

51 'Księga osob szlachetnie urodzonych w konwencie wielebnych Panień krokowskich', 1. $16 \mathrm{v}-17 \mathrm{v}$. In the visitation of 1677 , it was written that on 25 February 1650, Tyszkiewicz confirmed the transfer of the house of the Krakès parish priest, Butkiewicz, to the sisters. See: Žemaičiu vyskupo Kazimiero Paco 1675-1677 m. sudaryti vizitaciju aktai, p. 725.

${ }^{52}$ Visitation of the Krakès convent of the Sisters of St Catherine, 1820, LVIA, f. 669 , ap. 2, b. $224,1.203 \mathrm{v}$. 
On 21 January 1651, Bishop Piotr Parczewski of Samogitia wrote in the reformation decree of his visitation to the Krakès parish that he confirmed the choice of the professed young women who had taken vows according to the rules of living by the church. ${ }^{53}$ There were no details, however, about which rules in particular these were.

The contribution of the King of Poland and Grand Duke of Lithuania John Casimir Vasa is important in the founding of the Krakès convent. On 23 April 1653, he transferred the villages of Aleknaičiai and Šiukštaičiai in the Tendžiogala volost to the Krakès Sisters of St Catherine, as their previous owner Krystyna Szołkowska-Białłozorowa (Šalkauskaitè-Bialozorienè), the wife of the Marshal of Upyte, had died. In this note from the ruler, the Krakes convent is referred to for the first time as a convent of the Congregation of St Catherine. On 16 May, Cyprian Paweł Brzostowski (Bžostovskis), the referendary of the GDL, confirmed the transfer of these two villages to the Krakès Sisters of St Catherine, thereby also using the St Catherine concept. However, on 19 May, the Bishop of Vilnius Jerzy Tyzkiewicz confirmed this grant made by the ruler to the 'chaste noblewomen' (he did not refer to them as Sisters of St Catherine). ${ }^{54}$ The devout women of Krakès were given the inventory of these two villages which had been made on 13 March. ${ }^{55}$ The ruler and Bishop Jerzy Tyszkiewicz thus became founders of the convent.

Documents dating from 1653 reveal an interesting fact: Bishop Tyszkiewicz did not call the Krakès community Sisters of St Catherine, but referred to them as members of the secular nobility. Yet the ruler

53 Žemaičiu vyskupijos vizitaciju aktai (1611-1651 m.), p. 358. 'Virgines Professae in regula sibi data, penes Ecclesiam hanc residentes, et in omnibus immunitatibus debitis ab Ill.mo et Reverendissimo D.no D.no Petro Parczewski, Episcopo Samogitiae, confirmatae et approbatae'.

${ }^{54}$ Note of John Casimir Vasa, Brest, 23 April 1653, in: Visitation of the Krakès convent of the Sisters of St Catherine, 16 February 1805, LVIA, f. 1671, ap. 4, b. 369, 1. 13v; Manuscript Department of the Wrublewski Library of the Lithuanian Academy of Sciences, f. 43-1075, 1. 16-17 (another copy of the document); note by C.P. Brzostowski, 16 May 1653, in: Visitation of the Krakès convent of the Sisters of St Catherine, 16 February 1805, LVIA, f. 1671, ap. 4, b. 369, 1. 12v-13; note by J. Tyszkiewicz, Vilnius, 19 May 1653, in: Visitation of the Krakès convent of the Sisters of St Catherine, 16 February 1805, ibid., 1. 13-13v; Žemaičiu vyskupo Kazimiero Paco 1675-1677 m. sudaryti vizitaciju aktai, p. 725.

55 Visitation of the Krakès convent of the Sisters of St Catherine, 16 February 1805, LVIA, f. 1671 , ap. 4, b. $369,1.14-15 \mathrm{v}$. 
stated that they were Sisters of the Congregation of St Catherine. This suggests that at the time the desire was to have a branch of the congregation in Krakès, and that the Krakès convent was already considered by the common folk as belonging to the Congregation of St Catherine. However, this community had not yet been officially approved as a convent of this congregation.

Later sources are written retrospectively, knowing that the funding provided by Tyszkiewicz in 1645 laid the foundations for the establishment of the Sisters of St Catherine in Krakes. During a visitation to the Krakès convent on 6 February 1677, it was said that the convent of the Sisters of St Catherine in Krakès had been founded by Bishop Jerzy Tyszkiewicz in $1645 .{ }^{56} \mathrm{In}$ a document about the pastoral activities of Bishop Tyszkiewicz dating from around 1772, it was said that he formed a community of the Sisters of St Catherine in Krakès on 23 February 1645, which was granted funding by the ruler John Casimir Vasa on 23 April 1653. ${ }^{57}$

Historians have accepted this position. According to Błaszczyk, the Sisters of St Catherine became established in Krakès through the joint funding of Bishop Jerzy Tyszkiewicz (1645) and the ruler John Casimir Vasa (23 April 1653). The bishop had the convent and the church built, and invited sisters, while the ruler guaranteed a livelihood for the sisters. ${ }^{58}$ These acts are considered important in terms of the activities of Bishop Tyszkiewicz and the ruler John Casimir Vasa. Lithuanian historiography maintains that the official founder of the Krakès convent of the Congregation of St Catherine should be Bishop Jerzy Tyszkiewicz in $1645 .{ }^{59}$

56 Žemaičių vyskupo Kazimiero Paco 1675-1677 m. sudaryti vizitacijų aktai, p. 725 .

${ }^{57}$ Codex Mednicensis seu Samogitiae dioecesis, vol. 2, p. 516: 'Non cessavit tamen in illa etiam sede prospicere necessitatibus fundationum Samogitiensis dioecesis; memor enim se olim virgines aliquas nobiles Deo in castitate volentes servire penes ecclesiam parochialem Krokoviensem, dispersim primo habitantes, in unam domum collegisse easque ad formam certae congregationis sub invocatione sanctae Catharinae virginis martyris redegisse anno Domini 1645, die 23 februarii. Impetravit a Ioanne Casimiro rege Poloniae super pagis Olechnaycie et Szuksztaycie, intercedente Cypriano Paulo Brzostowski, referendario magni ducatus Lituaniae su anno 1653 mensis aprilis 23 die privilegium dotationis et fundationis, villasque praefatas possessioni harum sanctimonialium tradidit.'

${ }^{58}$ G. Błaszczyk, 'Fundacje i fundatorzy klasztorów diecezji Żmudzkiej w XVII i XVIII wieku’, in: Lituano-slavica posnaniensia. Studia historica I (1985), pp. 145-147.

${ }^{59}$ R. Janonienè, 'Krakių kotryniečių vienuolynas', p. 126. 
In summary, it can be said that the sparse and contradictory sources could perhaps lead to the assumption that in around 1651-1653, a more pronounced transformation could be seen in the Krakès community, whereby the devout young women were recognised as belonging to a convent of the Congregation of St Catherine, whose rapid and complete transformation was interrupted by the cataclysms beginning in 1654 .

\section{The introduction of the rule of the Congregation of St Catherine in $\mathbf{1 6 7 3}$}

The wars against Sweden and Russia of 1654 and 1655, the country's occupation and the accompanying famine, plague and demographic losses (the population of the GDL declined by a third to a half) put a halt to the development of the Krakès convent and its transformation into a community of the Congregation of St Catherine for some time. During this terrible period, ensuing bishops patronised the sisters, confirming and increasing the signing-over of property to the Krakes convent which had been initiated by their predecessors. This was done by Piotr Parczewski in 1655 and 1657, by Alexander Sapieha (Sapiega, bishop from 1660 to 1667 ) in $1661,{ }^{60}$ and by Kazimierz Pac (Pacas, bishop from 1667 to 1695 ) in 1670. ${ }^{61} \mathrm{~A}$ transfer of ownership made on 15 January 1671 testifies to something of a material recovery after the wars, whereby Pac donated to the sisters a lot of land with a dam by the river Smilga where a watermill was built. ${ }^{62}$ The time was approaching to see to the legitimisation of the community of the Sisters of St Catherine in Krakès.

The chaplain Pikturna's book about the Krakès sisters at the end of the 18th century states that the Bishop of Samogitia Kazimierz

${ }^{60}$ M. Valančius, 'Žemaičių vyskupystè', p. 323; Žemaičiu vyskupo Kazimiero Paco 1675-1677 m. sudaryti vizitaciju aktai, p. 725; Visitation of the Krakès convent of the Sisters of St Catherine, 1839, LVIA, f. 669, ap. 2, b. 50, 1. 161v; 'Księga osob szlachetnie urodzonych w konwencie wielebnych Panień krokowskich', KKA, b. 1, 1. 16v; B. Šopyte, 'Kaip Dievas nori', p. 84.

${ }^{61}$ Visitation of the Krakes convent of the Sisters of St Catherine, 1821, LVIA, f. 669 , ap. 2, b. 228 , 1. 233a.

62 Žemaičiu vyskupo Kazimiero Paco 1675-1677 m. sudaryti vizitaciju aktai, p. 725; 'Księga osob szlachetnie urodzonych w konwencie wielebnych Panień krokowskich', KKA, b. 1, 1. 16v; Visitation of the Krakès convent of the Sisters of St Catherine, 16 February 1805, LVIA, f. 1671, ap. 4, b. 369, 1. 10v-11; Visitation of the Krakès convent of the Sisters of St Catherine, 1839, ibid., f. 669, ap. 2, b. 250, 1. 161v. 
Pac, having observed that the Krakès community were living without an authorised set of rules, invited several people from the Warmian bishopric at his own expense to come to Krakès, in order to teach the devout women there how to live by the rule of the Congregation of St Catherine. On 11 January 1673, soon after being convinced that the women in Krakès were indeed abiding by the rules, the Bishop of Samogitia said a special Mass in the Krakès parish church, and received vows of chastity, poverty and obedience from Daratha Narbutówna (Narbutaite) from the Vilkmerge powiat, Sofia Jankiewiczówna (Jankevičiūte) from the Beržènai powiat, and Krystyna Lileykówna (Lileikaite) from the Varniai powiat, and ordered them to abide strictly by the rules and uphold stability. ${ }^{63}$

However, a surviving copy of a letter dated 9 July 1668 from the Bishop of Warmia Jan Stefan Wydżga shows that even though two sisters had been invited to Krakès, they did not go, because the distance was too great, and because they could not speak Polish, and as a result they could not be of much use. All that was forthcoming was the mentioned letter from the Bishop of Warmia in 1668, and the rule of the Congregation of St Catherine from 1602, translated into Latin. In his letter, the bishop noted that four convents in his bishopric abided by this particular rule. The documents from 1668 were given to the Krakes superior Marianna Salomeaa Siemaszkówna (Semaškaitè). ${ }^{64}$ So the sources only give an indication of Pac'

63 'Księga osob szlachetnie urodzonych w konwencie wielebnych Panień krokowskich', KKA, b. 1, 1. 8v-9: 'JWJX Kazimierz Pac biskup Zmuydci z troskliwości pasterskiey poznawajac, iż wielebne Panny krokowskie nie sq stałe $w$ swoich regułach y ustawach utwierdzone, a o powinnościach y postanowieniu swoim niewiadome, nająt niektóre osoby swoim kosztem y zprowadzit z biskupstwa warminskiego do Krok dla przyuczenia się tuteyszym pannom przycięgle tegosz postanowienia y tych że regut za mistrzynie y starsze, a w krotkim czasie przy nich gdy za Boża pomoca zpilnego dowiadczenia tenże JWJX Kazymierz Pac biskup Żmuydzki juź w swoich regułach doskonate zostajęce ogładat, przybywszy do Krok roku 1673 dnia 11 januarij w Bogu WJ Pannę Dorothę Narbutownę z powiatu wilkomierskiego, WJ Pannę Zofia Jankiewiczownę z powiatu berźańskiego y Chrystynę Lileykownę z powiatu wornienskiego przy odprawieniu Mszy swiętej solenney $w$ kosciele parafialnym krokowskim juramente y professyi z naocznym głosem na czystość, ubostwo y postuszeństwo do nich iuź zachowane wystuchawszy pomienionych panien zgromadzenia wyźwspomienionego, y przez antecessorów swoich przywilejami umocnionego $w$ towarzystwo policzyl, postanowienia y reguty aby jak nayprzykladniey byly zachowane, klauzurę obwarowawzy y umocniwszy w imie Pańskie poddat $i$ oddat.'

${ }^{64}$ Letter from the Bishop of Warmia J.S. Wydżga to M. Semaškaite, Heilsberg, 9 July 1668, in: 'Księga osob szlachetnie urodzonych w konwencie wielebnych 
intention to invite some Sisters of St Catherine from Warmia, but alas, they were never realised. The rules of the Congregation of St Catherine were simply sent to Krakès, and the sisters there had to learn how to live by them themselves. Pikturna, whose report was made 100 years after the period in question, was most likely wrong in stating that Sisters of the Congregation of St Catherine from Warmia had arrived in Krakès around 1668-1673.

Bishop Pac of Samogitia confirmed the rule of the Sisters of St Catherine from 1602 in Polish for the Krakès sisters on 21 February 1673. ${ }^{65}$ Thus, the rules that had been received in Latin in 1668 were translated into Polish some time before 1673. Not all the noblewomen could speak Latin, and in practical life, a Polish version of the rules was necessary. ${ }^{66}$

The rules for the Krakès sisters confirmed by Pacas in 1673 were not so different from the 1602 rules, with only some points being adapted to fit the local conditions. The last of the paragraphs (number 27) was not included into the rules. This paragraph declared that the St Catherine convents of Warmia bishopric were obedient to the General Mother residing in Braniewo. Instead of this paragraph, there appeared an inscription by the Samogitian Bishop K. Pac. In this text, he had confirmed this regula and earlier privileges by Samogitian Bishops given to the convent. This proves that the Krakès convent was in full disposal of Samogitian Bishop.

Next to this main difference, the saints of the Braniewo parish had been changed to the Krakès parish saints. It was said that the Krakès sisters had to attend Mass in the convent chapel, where the sermon was to be preached by the chaplain in Polish and not in

Panień krokowskich', KKA, b. 1, 1. 61. Śliwińska published the letter in Polish and German: B. Śliwińska, Geschichte der Kongregation, p. 186; B. Śliwińska, Dzieje Zgromadzienia, t. 1, pp. 171-172: 'Moglyby byly jechać i dwie tuteczne zakonnice, ale nie zebrało się na to tak prędko, bo i ten pan, który tu przyjechat, nie ma wygody dla nich zajechania i trzeba by upatrzyć dopiero po klasztorach panien dobrze wiadomych i po po polsku umiejacych, abyście Waszmoście z ukontentowaniem swoim miały z nich ustuge.'

${ }^{65}$ Note by K. Pacs, Alsèdžiai, 21 February 1673, in: 'Księga osob szlachetnie urodzonych w konwencie wielebnych Panień krokowskich', KKA, b. 1, 1. 65; 'Reguła Panen zakonnych S. Katarzyny męczenniczki w dyecezyi Zmudzkiey w m. Krokach', KKA, 1. 11; document published in: B. Śliwińska, Dzieje Zgromadzienia, t. 1, p. 172; B. Śliwińska, Geschichte der Kongregation, pp. 186-187.

66 'Księga osob szlachetnie urodzonych w konwencie wielebnych Panień krokowskich', KKA, b. 1, 1. 61v-65; 'Reguła Panien zakonnych S. Katarzyny Męczenniczki w dyecezyi Zmudzkiey w m. Krokach', KKA, 1. 2-11v. 
Samogitian. ${ }^{67}$ The convent's servants had to pray in the same chapel, except for Easter and Christmas, when they could go to the parish church. The chaplain could only offer the sacraments without the priest's knowledge to the sisters and their servants. However, on feast days of patronal saints, all believers who wished to could attend Mass, and be administered the sacraments in the convent chapel.

In the rules of Braniewo, as well as in those of Krakès, it was declared that the Sisters of St Catherine could not nurse men, except in extreme cases. However, the sisters could nurse ill women, and educate girls in the convent, and if the need arose, they could even leave the convent if they were accompanied.

Based on the set daily routine, the Krakès sisters had to wake up at $4 \mathrm{am}$; they then had 30 minutes to get dressed and tidy up, whilst thinking pious thoughts. Afterwards, the sisters would gather in the chapel for the Litany of the Blessed Virgin Mary, and chant the Hours of the Virgin (called kurs in Polish). After these prayers came Mass, following which they could engage in some work or other activity. Lunch was at 10 am (at midday during times of fasting). A 15-minute-long conscience session and prayers whilst kneeling was held before lunch: five Our Fathers and five Hail Marys. Grace was said before and after meals. Readings from the Bible would be read aloud while the sisters ate, to feed the soul. Before dinner, at 6.30 $\mathrm{pm}$, the Rosary would be said. In the evening before going to bed, 30 minutes would be devoted to an examination of the conscience and devout considerations, and the Litany of the Saints would be recited. The sisters went to bed at $9 \mathrm{pm}$.

The Rosary would be said with different intentions every day of the week. On Sundays, it was dedicated to the congregation and the improvement of the sisters, on Mondays it was said for the deceased,

${ }^{67}$ The ban on giving sermons in Samogitian is evidence that this language was nonetheless used among the sisters. Polish was the lingua franca at the time, the universal language in public life, and was also used for publications of religious literature. By then, only the Catechism, Postille, a hymnal and Book of the Gospel and the Rosary had been published in Samogitian (Lithuanian), which might have been enough for ordinary believers, but was insufficient for nuns and monks who heeded the calling to take a deeper interest in religious thought, to improve themselves spiritually, and to learn from religious readings. So, even those Samogitian or Lithuanian girls who had a poor knowledge of Polish would have had to learn it on arriving at the Krakès convent, and to improve their knowledge of the language in everyday life, listening to the priest's sermons, reading the Bible, and saying the Rosary and other prayers in Polish. 
on Tuesdays for the clergy, on Wednesdays for the secular government, on Thursdays for the brothers (monks), on Fridays for those who did good deeds, and on Saturdays each sister would say the Rosary for herself, that she might endure her chosen path until her last days.

These were the main tasks of the Sisters of St Catherine, allowing time in the day for prayer and work. The mother superior would run the convent for three years after receiving a majority of votes in a secret ballot. She would be assisted by two advisors, who were also voted for. This threesome would constitute the convent board. Sisters were allocated duties: the door-sister was responsible for ensuring stability, the magistrate looked after teaching novices, etc. Girls could enter the convent from the age of 16. The novitiate lasted a year, in which time the girl would study, the strength of her calling would be tested, and she would become familiar with the way of life of the community. After the novitiate, exams and testing, perpetual vows would be taken, and the girl would join the convent for the rest of her life. The convent came under the jurisdiction of the bishop or one of his assignees, and no important decisions could be made without his knowledge, such as the election of a superior, taking perpetual vows, or handling the convent's property.

According to data from the convent's visitation in 1677, the Krakès sisters lived in a wooden house, which had 14 cells and a refectory. The main building in the convent was a wooden chapel, where a painting of the Holy Trinity hung above the main altar. Above it was a baldachin painted in various colours, where an image of Jesus as Judge was displayed. To the right of the altar was a niche containing a carved figure of The Suffering Christ on a black cross. A statue of the Blessed Virgin Mary, placed behind glass, stood to the left of the altar. Relics of saints Valentine, Lawrence and Margaret were kept on the altar, which had been approved by Bishop Jerzy Tyszkiewicz. A space for a choir was made above the entrance to the chapel, which could be reached by stairs straight from the convent itself. The choir was separated from the rest of the chapel by a wooden grate, ensuring stability. The convent was surrounded by a log fence. ${ }^{68}$ (Note that no image of St Catherine in the chapel was mentioned in the visitation. This raises the question whether one existed at all, or whether it had simply not been listed in the source.)

68 Žemaičiu vyskupo Kazimiero Paco 1675-1677 m. sudaryti vizitaciju aktai, pp. $726,728$. 
The visitation of 1677 showed that the way of life of the Krakès Sisters of St Catherine was properly organised, and that the rule was followed. The reform decree stressed that stability had to be strictly adhered to, that a diligent door-sister was necesary, and that the convent could not be left without the prior permission of the local registrar, unless death or extreme danger threatened. The mother superior was given strict orders to see that no arguments or disputes arose within the community. The sisters had to remain devout, and worship the Lord and all the saints, especially St Catherine, and the convent's patron. ${ }^{69}$ Seven sisters participated in the election of a new superior in 1677, suggesting that this was the number of sisters residing in the convent at the time. ${ }^{70}$ Sources show that all the girls admitted to the Krakès convent during the times of the GDL were of noble origin. On its foundation in 1645, Bishop Tyszkiewicz had indicated that it was for noblewomen.

The papal nuncio Giacomo Cantelmi confirmed the rule of the Congregation of St Catherine for the Krakès convent on 28 March 1689 in Warsaw, which was the final permission for the sisters to officially base their lives on the congregation's provisions. The nuncio wrote that the rule did not contradict the resolutions reached at the Council of Trent. ${ }^{71}$ Śliwińska considers the authorisation of the rule of the Congregation of St Catherine for the Krakès sisters as a repeated creation of a branch of the community in Samogitia. ${ }^{72}$ We could agree with her, saying that it was from this moment that the Krakès community could be officially referred to as a convent following the rule of St Catherine the Virgin Martyr. After 1673, life for the Sisters of St Catherine in Krakès ultimately attained its proper order.

The German historian Meiwes correctly noted that the Lithuanian Sisters of St Catherine differed from their counterparts in the Warmian bishopric. ${ }^{73}$ Indeed, the differences between the Krakès convent and the Warmian convents were obvious. Whereas Warmian convents of

${ }^{69}$ Ibid., pp. 731-732.

${ }^{70}$ Ibid., pp. 727-728.

${ }^{71}$ G. Cantelmi confirms the rule of the Krakès Sisters of St Catherine, Warsaw, 28 March 1689, 'Reguła Panien zakonnych S. Katarzyny Męczenniczki w dyecezyi Zmudzkiey w m. Krokach', KKA, 1. 11v-13r, in: B. Śliwińska, Dzieje Zgromadzienia, t. 1, p. 173; B. Śliwińska, Geschichte der Kongregation, pp. 187-188.

${ }^{72}$ B. Śliwińska, Dzieje Zgromadzienia, t. 1, p. 119.

${ }^{73}$ R. Meiwes, Von Ostpreußen in die Welt, p. 63. 
the Congregation of St Catherine were located in Prussian German towns, and were constructed of brick, the Krakès convent was established in a rural area, in the township of Krakès, where only in 1790 did the ruler grant a charter to hold markets and three fairs a year. ${ }^{74}$ The sisters built an ordinary wooden convent and a church. While in Warmia it was mostly female burghers or young peasant women who entered the convents of the congregation, Krakès accepted noblewomen. The devout women of Krakès engaged less in charitable activities, devoting themselves more to a contemplative life. Meiwes writes that religious life in the Krakès convent adhered to the strict rule of Catholic convents, where a religious and contemplative life took precedence over the vocation to teach and engage in social work. ${ }^{75}$ The Sisters of St Catherine in Krakès were heavily influenced by the Bishop of Samogitia, and maintained only loose contacts with Braniewo. In summary, it could be said that the physical surroundings, social origins, living conditions, language and customs of the Prussian and Samogitian sisters differed. Basically, there was a Lithuanian version of the Sisters of St Catherine, which became increasingly more distinct in later years.

\section{Conclusions}

At the initiative of Bishop Jerzy Tyszkiewicz of Samogitia, a convent for young noblewomen was founded at the Krakes parish church in 1645, which developed into a community of Sisters of St Catherine under the patronage of the Bishop of Samogitia. In 1673, Bishop Kazimierz Pac of Samogitia confirmed the rule of the Congregation of St Catherine received from Braniewo in 1668 for the Krakès community, having made some amendments. The rule of the Krakès Sisters of St Catherine was approved by the papal nuncio Giacomo Cantelmi in 1689. The Krakès sisters followed this rule until the beginning of the 20th century.

The Krakès convent of the Sisters of St Catherine grew and developed in a different environment to the mother-convent of the Braniewo Sisters of St Catherine, which was founded in 1571 by the German burgher (now beatified) Regina Protmann. The Krakès convent was not closely tied with Braniewo. It is believed that at

${ }^{74}$ E. Meilus, Žemaitijos kunigaikštystès miesteliai XVII a. II pusejje - XVIII a. (raida, gyventojai, amatai, prekyba) (Vilnius, 1997), pp. 32, 164.

${ }^{75}$ R. Meiwes, Von Ostpreußen in die Welt, p. 63. 
no point in the establishment of the Krakès convent did a single Warmian sister visit to teach the Krakes sisters directly how to live in accordance with the rule of their congregation. This was not only due to the fact that the convents were founded in different bishoprics, but also due to the social, linguistic and cultural differences, not to mention the physical distance. Under the guidance of the Bishop of Samogitia, the Krakès convent created a version of the Sisters of St Catherine unique to the GDL. The Krakès sisters were of noble origin, and abided by a stricter rule, devoting less time to social, charitable and educational activities.

During the 17th century, the Krakès convent grew into a small but stable community, respected in society, which abided by the principles of the Congregation of St Catherine (seven sisters were mentioned in 1677 , even though there were 14 cells, suggesting that their numbers were expected to increase). The convents of the Sisters of St Catherine in Krakès and the Benedictines in Kražiai were the only communities of nuns authorised by the Holy See in the Diocese of Samogitia in the 17th century.

\section{Author Details}

Dr Vaida Kamuntavičiene is a professor in the Faculty of History at Vytautas Magnus University. Her academic fields of interest are the history of the Grand Duchy of Lithuania, the history of convents, and micro-history.

Address: V. Putvinskio St., 23 Kaunas, Lithuania

E-mail: v.kamuntaviciene@gmail.com

\section{Bibliography}

BŁASZCZYK, Grzegorz. Diecezja żmudzka od XV wieku do początku XVII wieku.Ustrój (Poznań, 1993).

BŁASZCZYK, Grzegorz. 'Fundacje i fundatorzy klasztorów diecezji Żmudzkiej w XVII i XVIII wieku', in: Lituano slavica posnaniensia, Studia historica I (Poznań, 1985).

BŁASZCZYK, Grzegorz. 'Stan badań nad klasztorami diecezji żmudzkiej', in: Zakony i klasztory w Europie Środkowo - Wschodniej. X-XX wiek. Materiały międzynarodowego seminarium pod tytutem „Atlas ruchu zakonnego w Europie Środkowo - Wschodniej. X-XX wiek', Lublin, 25-27 listopada 1993, eds. H. Gapski, J. Kłoczowski (Lublin, 1999).

BORKOWSKA Małgorzata. Leksykon zakonnic polskich epoki przedrozbiorowej, t. 3: Wielkie Księstwo Litewskie i Ziemie Ruskie Korony Polskiej (Warszawa, 2008). 
BORKOWSKA, Małgorzata. Panny siostry w świecie sarmackim (Warszawa, 2002).

BORKOWSKA, Małgorzata. Zakony żeńskie $w$ Polsce $w$ epoce nowożytnej (Lublin, 2010).

GRIGALIŪNAITĖ, Roberta. 'Krakių kotryniečių vienuolijos sudètis XVII-XVIII a.', in: Lietuvos Didžiosios Kunigaikštystés moteru vienuolijos: istorija ir paveldas, ed. A. Vasiliauskienė (Kaunas, 2014), pp. 141-154.

JANONIENĖ, Rūta. 'Krakių kotryniečių vienuolynas', in: Lietuvos vienuolynai. Vadovas (Vilnius, 1998), pp. 126-127.

JATULIS, Paulius. (ed.) Codex Mednicensis seu Samogitiae dioecesis, vol. 2 (Roma, 1989).

JOVAIŠA, Liudas. 'Neinstitucinè moterų vienuolystė? Davatkos Žemaitijoje XVII-XVIII a.', in: Lietuvos Didžiosios Kunigaikštystès motery vienuolijos: istorija ir paveldas, ed. A. Vasiliauskienė (Kaunas, 2014), pp. 47-68.

JOVAIŠA, Liudas. (ed.) Žemaičiu vyskupijos vizitacijų aktai (16111651 m.) (Vilnius, 2011).

JUČAS, Mečislovas. Lietuvos parapijos XV-XVIII a. (Vilnius, 2007).

KAMUNTAVIČIENÉ, Vaida. Kauno benediktiniu vienuolyno tyrimai, t. 1, Kauno benediktiniu vienuolyno istorija (Kaunas, 2016).

KVIKLYS, Bronius. Lietuvos bažnyčios, t. 3 (Chicago, 1983).

KVIKLYS, Bronius. Mūsu Lietuva, t. 2 (Boston, 1965).

LEBEDYS, Jurgis. Mikalojus Daukša (Vilnius, 1963).

MEILUS, Elmantas. Žemaitijos kunigaikštystès miesteliai XVII a. II pusejje - XVIII a. (raida, gyventojai, amatai, prekyba) (Vilnius, 1997).

MEIWES, Relinde. Klosterleben in bewegten Zeiten. Die Geschichte der ermländischen Katharinenschwestern (1914-1962) (Paderborn, 2016).

MEIWES, Relinde. Von Ostpreußen in die Welt. Die Geschichte der ermländischen Katharinenschwestern (1772-1914) (Paderborn, 2011).

MISIUS, Kazys, ŠINKŪNAS, Romualdas. Lietuvos kataliku bažnyčios (žinynas) (Vilnius, 1993).

PAKNYS, Mindaugas. (ed.) Žemaičiu vyskupo Kazimiero Paco 1675 1677 m. sudaryti vizitaciju aktai (Vilnius, 2011).

RABIKAUSKAS, Paulius. (ed.) Relationes status dioecesium in Magno Ducatu Lithuaniae, vol. 1: Dioeceses Vilnensis et Samogitiae (Roma, 1971).

ŚLIWIŃSKA, Barbara. Dzieje Zgromadzienia Sióstr Świętej Katarzyny Dziewicy i Męczennicy 1571-1772 (Olsztyn, 1996).

ŚLIWIŃSKA, Barbara. Dzieje Zgromadzienia Sióstr Świętej Katarzyny Dziewicy i Męczennicy, t. 1: 1571-1772 (Olsztyn, 1998).

ŚLIWIŃSKA, Barbara. Geschichte der Kongregation der Schwester der heiligen Jungfrau un Martyrin Katharina 1571-1772 (Münster, 1999).

ŚLIWIŃSKA, Barbara. 'Zgromadzienie sióstr świętej Katarzyny Dziewicy Męczennicy na Litwie (1645-1995)', in: Studia Warmińskie, nr. XXXIII (1996), pp. 273-293.

VAIŠNORA, J. 'Kotrynietès', in: Lietuviu enciklopedija, t. 12 (Boston, 1957).

VALANČIUS, Motiejus. 'Žemaičių vyskupystè', in: Raštai, t. 2 (Vilnius, 1972). 


\title{
KRAKIŲ KOTRYNIEČIŲ VIENUOLYNO FUNDACIJA XVII A.
}

\author{
Santrauka
}

\section{VAIDA KAMUNTAVIČENE்}

Katalikų bažnyčios reformos epochoje $1571 \mathrm{~m}$. Varmès (Ermlando) vyskupijos Braunsbergo (šiuo metu lenk. Braniewo) miestietė Regina Protmann (1552-1613; 1999 m. paskelbta palaimintaja) ịkūrè Šv. Kotrynos Aleksandrietès Mergelès ir Kankinès kotryniečių bendruomenę. 1602 m. Apaštalų Sosto nuncijus Claudio Rangoni Vilniuje patvirtino kotryniečių kongregacijos regulą. Jos narès duodavo neturto, skaistumo ir paklusnumo įžadus, tačiau laikydavosi negriežtos klauzūros, pasiryždavo tarnauti žmonėms, slaugyti kenčiančius, mokyti ir šviesti visuomenę. Kotrynietès buvo populiarios Varmeje, garsas apie jas pasieke ir Žemaitiją.

Žemaičių vyskupo Jurgio Tiškevičiaus iniciatyva $1645 \mathrm{~m}$. prie Krakių parapinès bažnyčios buvo funduotas kilmingų panelių (dievotų) vienuolynas, kuris išaugo ị Žemaičių vyskupų globojamą kotryniečių bendruomenę. 1673 m. Žemaičių vyskupas Kazimieras Pacas Krakių kotrynietėms patvirtino ị lenkų kalbą išverstą 1668 m. iš Braunsbergo gautą kotryniečių kongregacijos regulą, atlikęs nedidelius jos pakeitimus. Krakių kotryniečių regulą aprobavo Apaštalų Sosto nuncijus Giacomo Cantelmi Varšuvoje 1689 m. Šia regula krakiškès vadovavosi iki XX a. pradžios.

Straipsnyje atskleidžiamas Krakių kotryniečių fundacijos procesas, daromos išvados, kad Krakių vienuolyno fundacija užtruko dèl XVII a. vidurio Abiejų Tautų Respublikos karų su Rusija ir Švedija. Straipsnyje parodomi Žemaitijos kotryniečių skirtumai nuo Varmès vyskupijos kotryniečių. Krakių vienuolynas palaikẻ silpnus ryšius su Braunsbergu, tikètina, kad nè vienu Krakių vienuolyno kūrimosi etapu jame neapsilankė jokia Varmès kotryniete tiesiogiai pamokyti, kaip gyventi pagal kotryniečių regulą. Tai lèmé ne tik tai, kad vienuolynai buvo funduoti skirtingose vyskupijose, bet ir materialiniai (Varmès kotryniečių vienuolynai buvo mūriniai, Krakių - medinis), socialiniai (Varmès kotrynietès daugiausia buvo miestietès, Žemaitijos - bajoraitès), kalbiniai (Varmès kotrynietès kalbėjo vokiečių k., Žemaitijos - pamaldose meldèsi lenkų k.) bei kultūriniai (Krakių vienuolès laikèsi griežtesnès klauzūros, mažiau dėmesio skirdamos visuomenès karitatyvinei ir šviečiamajai veiklai) skirtumai, geografinis atstumas. Krakių vienuolynas, padedamas Žemaičių vyskupų, per XVII a. išaugo ị nedidelę, tačiau stabilią, visuomenėje gerbiamą bendruomenę (1677 m. paminètos 7 seserys, bet vienuolyne buvo 14 celių, taigi, numatytas augimas), sukūrè savitą Lietuvos Didžiosios Kunigaikštystès kotrynietès tipą. 